\title{
EDITORIAL: CONVENTIONS FOR REPORTING RADIOCARBON DETERMINATIONS
}

Since the landmark paper of Stuiver and Polach (1977), little has changed in the reporting of radiocarbon measurements, apart from some minor adjustments (Stuiver 1980, 1983). There have been several attempts to introduce modifications to terminology or calculations, but these are not widely used (e.g. Mook and van der Plicht 1999; Nadeau and Grootes 2013). The question of calibration and how these results are reported has not really been addressed.

In this issue, Millard (2014) proposes a comprehensive way to standardize the method of reporting of dates, as well as calibrated ages. He has the support of some 40 colleagues who endorse his proposal. In this summary, some important conventions are re-emphasized and some new ones introduced. We also endorse these recommendations and note a few additional problems that could perhaps be addressed by the next Radiocarbon conference. We add some editorial comments to the list of Millard (2014) below; we encourage reviewers and authors to follow these guidelines.

1. The laboratory result should be reported in a standard way, as fraction modern carbon (with appropriate fractionation corrections) or the "conventional radiocarbon age," as defined in Millard (2014) from previous conventions.

2. The laboratory code should always be included. Recently, many reports use sample designations of the originating users, which is not necessarily traceable.

3. The sample material, pretreatment, and quality control measurements, where applicable. We would note that many ${ }^{14} \mathrm{C}$ dates are reported other than by the laboratory itself. Hence, those reports and papers should incorporate a reference to the source laboratory.

4. The calibration curve, method of calculation (software), and any offsets used such as reservoir corrections should be reported. Millard (2014) gives more detail as to how this should be done. We note that revisions to various calibration curves and software mean that the same calibrated age range will not result if different calibrations (e.g. IntCal13 vs. IntCal09; Reimer et al. 2009, 2013) or different software are used.

5. Appropriate and defensible errors should be reported. The end-user may be unfamiliar with the way in which errors are estimated at your laboratory. If possible, each laboratory should make their methods of calculation available - if not in publication, then by request of the user.

6. Problematic events in the laboratory that might have affected the user's results need to be reported back to users. These could include machine problems, electronic problems, human errors (e.g. sample mislabeling), and contamination events by samples enriched in ${ }^{14} \mathrm{C}$. $\mathrm{Al}-$ though most laboratories strive to avoid these types of samples, it is inevitable that, at some time, a laboratory will process an enriched sample. Good record-keeping as well as the frequent analysis of background samples are required to document and understand the impact of these samples. Recently, some laboratories have been analyzing both natural-level and enriched ${ }^{14} \mathrm{C}$ samples. Hence, these laboratories need to be especially vigilant in ensuring that unexpected contamination events do not occur.

We commend Millard (2014) for raising these questions and we anticipate that there should be a healthy discussion of these issues at future scientific meetings.

\section{A J T Jull and A P McNichol}




\section{REFERENCES}

Millard AR. 2014. Conventions for reporting radiocarbon determinations. Radiocarbon 56(2), these proceedings.

Mook W, van der Plicht J. 1999. Reporting ${ }^{14} \mathrm{C}$ activities and concentrations. Radiocarbon 41(3):227-39.

Nadeau M-J, Grootes PM. 2013. Calculation of the compounded uncertainty of ${ }^{14} \mathrm{C}$ AMS measurements. Nuclear Instruments and Methods in Physics Research B 294:420-5.

Reimer PJ, Baillie MGL, Bard E, Bayliss A, Beck JW, Blackwell PG, Bronk Ramsey C, Buck CE, Burr GS, Edwards RL, Friedrich M, Grootes PM, Guilderson TP, Hajdas I, Heaton TJ, Hogg AG, Hughen KA, Kaiser KF, Kromer B, McCormac FG, Manning SW, Reimer RW, Richards DA, Southon JR, Talamo S, Turney CSM, van der Plicht J, Weyhenmeyer CE. 2009. IntCal09 and Marine09 radiocarbon age calibration curves, 0-50,000 years cal BP. Radiocarbon 51(4):1111-50.
Reimer PJ, Bard E, Bayliss A, Beck JW, Blackwell PG, Bronk Ramsey C, Buck CE, Cheng H, Edwards RL, Friedrich M, Grootes PM, Guilderson TP, Haflidason H, Hajdas I, Hatté C, Heaton TJ, Hoffmann DL, Hogg AG, Hughen KA, Kaiser KF, Kromer B, Manning SW, Niu M, Reimer RW, Richards DA, Scott EM, Southon JR, Staff RA, Turney CSM, van der Plicht J. 2013. IntCal13 and Marine13 radiocarbon age calibration curves $0-50,000$ years cal BP. Radiocarbon 55(4):1869-87.

Stuiver M. 1980. Workshop on ${ }^{14} \mathrm{C}$ data reporting. Radiocarbon 22(3):964-6.

Stuiver M. 1983. Business meeting: international agreements and the use of the new oxalic acid standard. Radiocarbon 25(2):793-5.

Stuiver M, Polach HA. 1977. Discussion: reporting of ${ }^{14} \mathrm{C}$ data. Radiocarbon 19(3):355-63. 